\title{
ALASDAIR MACINTYRE E A ÉTICA NIETZSCHIANA: APONTAMENTOS PARA UMA REFLEXÃO CRÍTICA
}

\author{
Helder Buenos Aires de Carvalho \\ Universidade Federal do Piauí
}

\begin{abstract}
This paper aims to criticize Maclntyre's reading of Nietzsche's Moral Philosophy in his books After Virtue and Whose Justice? Which rationality? in order to show misunderstandings of nietzschean perspective, as well as to figure out how Maclntyre incorporates significantly in his own philosophical approach conceptual contents of Nietzsche's genealogical approach.
\end{abstract}

Keywords: Nietzsche, Macintyre, moral.

Resumo: 0 artigo busca problematizar a leitura que Maclntyre faz da filosofia moral nietzschiana em suas obras After Virtue e Justiça de Quem? Qual Racionalidade?, de modo a evidenciar possíveis incompreensões da perspectiva nietzschiana, bem como mostrar que Maclntyre se apropria de elementos conceituais de Nietzsche de forma significativa.

Palavras-Chave: Nietzsche, Maclntyre, moral.

\section{Introdução}

Nietzsche é um daqueles filósofos que se parece mais com um torpedo, tanto no senso comum como no meio acadêmico. Sua leitura gera controvérsias, não deixa o seu leitor passivo, provoca-o, ao mesmo tempo não se deixa dominar. Interpretá-lo é sempre um desafio, uma necessária tensão sempre se instala entre o intérprete e sua escritura. Sua obra é repleta de afirmações que se contradizem, sua reflexão não é estática, mas dinâmica, um pensamento inquieto, que se recusa à leitura fácil. Como toda grande filosofia, seu pensamento foi vulgarizado e trivializado, gerando as mais díspares interpretações. Assim, ler Nietzsche é penetrar num universo 
labiríntico, em que a prudência é mais que essencial para não chegar a conclusões apressadas acerca do sentido de suas asserções fundamentais, para separar o joio do trigo, o estilo do conteúdo, a sedução da filosofia. O caráter polêmico é inerente à sua obra, tanto no método e no estilo, quanto nos temas e nas conclusões. E o próprio Nietzsche, enquanto pessoa humana particular, também encarnou essa polemicidade, sua vida movimentada acabou contribuindo para alimentar esse aspecto labiríntico de sua reflexão.

A reação à obra de Nietzsche tem um caráter pendular: "Ora ele é considerado um canalha, precursor do nazismo, um monstro. Ora ele é considerado um iconoclasta, um liberador, um benefício para a humanidade". ${ }^{1}$ Do Nietzsche gideano, defensor dos impulsos secretos e da pureza pessoal; passando pelo Nietzsche nazista, detrator da moral cristã e da democracia, elogioso das "bestas loiras"; e pelo Nietzsche desnazificado, não anti-semita, até o Nietzsche campeão da liberdade individual, da autorealização, um mestre da suspeita, crítico radical da civilização e da cultura. $^{2}$

Essa dificuldade de compreender a filosofia de Nietzsche é reforçada pela forma de sua obra, "aparentemente de acesso mais fácil, que atrai pelo brilho do seu estilo, pela forma aforística, que seduz pela temeridade de suas formulações, que enfeitiça pela beleza dos seus textos, que atordoa pela magia das suas posições extremas". ${ }^{3}$ Diante disso tudo, porém, não estamos imbuídos do espírito daqueles que afirmam que "Nietzsche fundou o terrorismo do pensamento" 4 ou que pretendem promover uma demolição do seu pensamento através dos instrumentos conceituais por ele mesmo forjados, ${ }^{5}$ mas sim que "está na hora de enfrentarmos, sem intermediações, a provocação da fala de Nietzsche: corrosiva, mas também construtiva”. ${ }^{6}$

Nosso trabalho não atinge a totalidade da obra de Nietzsche, referindo-se essencialmente às obras Genealogia da Moral, Verdade e Mentira no sentido Extra-Moral e $O$ Nascimento da Tragédia. E vamos tomar como objeto de análise a leitura de Nietzsche feita pelo neoaristotélico Alasdair

\footnotetext{
1 Coelho, 1994.

2 Sobre essas diferentes recepções da obra de Nietzsche, ver Marton (2010) e Tanner (2000).

${ }^{3}$ Fink, 1983, p.9.

${ }^{4}$ Coelho, 1994.

${ }^{5}$ Ferry et alii, 1994.

${ }^{6}$ Marton, 1994.
} 
MacIntyre, em suas obras After Virtue (1985) e Justiça de Quem? Qual racionalidade? (1991), em relação à problemática moral, buscando contrapôla ao texto nietzschiano, apoiando-nos em parte na interpretação de Eugen Fink (1983), a fim de levantar as insuficiências ali presentes. ${ }^{7}$ Ou seja, nosso objetivo é encontrar elementos na obra de Nietzsche que possam levantar suspeitas contra a validade da leitura macintyreana ou, pelo menos, complexificá-la. Contudo, não pretendemos também esgotar a posição de MacIntyre, ${ }^{8}$ pois esta estará tomada pontualmente, sem uma inserção mais completa no conjunto de sua obra, ou seja, os motivos que o levou a realizar essa leitura de Nietzsche, as forças vitais e conceituais que o movem não serão totalmente abordados. Portanto, nosso trabalho vai ser pontual em ambos os termos da problemática, tanto em Nietzsche, quanto em MacIntyre, não totalizante, assumindo plenamente o caráter de ensaio provisório, como apontamentos reflexivos.

$\mathrm{Na}$ leitura de MacIntyre, Nietzsche é caracterizado como um emotivista moral, ápice do individualismo liberal, postulador de um perspectivismo irracional e oposto à teorização aristotélica. Iremos discutir somente as três primeiras asserções, já que a última implicaria uma discussão mais extensa e profunda, que não comportaria em um único artigo. Nossa posição, a ser aqui desenvolvida, é de que a tentativa de MacIntyre em localizá-lo numa tradição determinada de pensamento - conceituada de um modo geral, a tradição liberal do individualismo - acaba por reduzi-lo a posições que o próprio Nietzsche criticaria em absoluto, caracterizando-se como uma leitura seletiva que desconsidera elementos importantes e que sugere possíveis insuficiências frente ao texto nietzschiano.

\section{MacIntyre leitor de Nietzsche}

Nietzsche é lido por MacIntyre na esteira da tese de fundo que desenvolve sistematicamente no seu livro After Virtue (1985), em relação à crise moral gerada a partir da emergência da modernidade, segundo a qual o fracasso na tentativa iluminista de fundar a moral racionalmente "não é outra coisa que a consequência histórica da rejeição da tradição aristotélica". 9

\footnotetext{
${ }^{7}$ Sobre como Nietzsche aparece em Three rival versions of moral enquiry (1990), ver Sousa (2010).

8 Para uma visão mais completa da filosofia de MacIntyre, ver Carvalho (1999).

${ }^{9}$ Maclntyre, 1985, p.117.
} 
Para ele, melhor do que qualquer outro pensador, foi Nietzsche quem percebeu o caráter de disponibilidade a qualquer tipo de uso da linguagem moral na modernidade, daí sua filosofia moral ser "uma das alternativas teóricas genuínas a que se enfrenta qualquer um que pretenda analisar a condição moral de nossa cultura". ${ }^{10}$ A façanha histórica de Nietzsche foi entender, mais claramente que qualquer outro filósofo, que aquilo que parecia ser apelo à objetividade - apelo característico do projeto filosófico do Iluminismo - era, de fato, expressões de vontade subjetiva, como também a natureza dos problemas que isto colocava para a filosofia moral. O erro de Nietzsche, para MacIntyre, foi que "ilegitimamente generalizou da condição do juízo moral em seu próprio tempo para a natureza da moral enquanto tal. (...) Mas é igualmente digno de nota que (...) isto é um insight genuíno". ${ }^{11}$

MacIntyre cita o $§ 335$ de A Gaia Ciência ${ }^{12}$ - em que Nietzsche zomba da noção de moralidade fundada nos sentimentos morais interiores, na consciência, de um lado, ou no imperativo categórico kantiano, de outro como referência para fundar sua interpretação da estrutura básica do argumento nietzschiano.

Se não há nada de moralidade, mas expressões de vontade, minha moralidade pode ser somente aquela que minha vontade criará. Não pode haver lugar para tais ficções como direitos naturais, utilidade, a maior felicidade para a maioria. Eu mesmo devo trazer a esta existência 'novas tábuas do que é o bem'. ${ }^{13}$

O sujeito moral autônomo racional e racionalmente justificado do Iluminismo é uma ficção, uma ilusão. Assim, para MacIntyre, Nietzsche resolve deixar a vontade substituir a razão e vamos nós mesmos nos transformarmos em sujeitos morais autônomos por um ato de vontade gigantesco e heróico. O problema, então, de como construir de um modo original, de como inventar uma nova tábua de valores, é um problema que emerge para cada indivíduo.

10 Idem, p.110.

11 lbidem, p.113.

12 Nietzsche, 1959, p.113.

${ }^{13}$ Maclntyre, 1985, p.114. 
Este problema constituiria o núcleo de uma filosofia moral nietzschiana. Pois é na sua implacavelmente séria perseguição do problema que reside a grandeza de Nietzsche, grandeza que faz dele $o$ filósofo moral se as únicas alternativas à filosofia moral de Nietzsche mostrarem-se ser aquelas formuladas pelos filósofos do Iluminismo e seus sucessores. ${ }^{14}$

Para MacIntyre, uma vez que o projeto iluminista da moralidade fundada racionalmente falhou, porque as posições desenvolvidas pelos seus protagonistas intelectuais mais poderosos, mais especialmente Kant, não puderam ser sustentadas em face de uma crítica racional, é que Nietzsche e todos os seus sucessores existencialistas e emotivistas foram capazes de produzir uma crítica aparentemente bem sucedida de toda a moralidade anterior. A associação de Nietzsche ao emotivismo, ${ }^{15}$ feita por MacIntyre, é explicitada claramente, aqui, quando ele afirma que todo o poder da posição de Nietzsche depende da validade de uma única tese central: "que toda justificação da moralidade manifestamente falha e que, portanto, a crença nos princípios da moralidade necessita ser explicada em termos de um conjunto de racionalizações que oculta o fenômeno fundamentalmente nãoracional da vontade". ${ }^{16}$

E avança essa caracterização quando lembra a arguição de R. Dworkin de que a doutrina central do moderno liberalismo é a tese de que questões como a vida boa para o homem ou os fins da vida humana - isto é, os valores orientadores da ação histórica do homem -devem ser vistos como, do ponto de vista público, como sistematicamente abertos, ou seja, "sobre isso os indivíduos são livres para concordarem ou discordarem". ${ }^{17}$ Nesse sentido, segundo a cultura emotivista, as normas morais, os valores éticos não são objetos de discussão racional, portanto, não há critérios universais válidos

\footnotetext{
14 Idem, p.114.

15 "Emotivismo é a doutrina de que todos os julgamentos valorativos e mais especificamente que todos os juízos morais não são nada mais que expressões de preferência, de atitudes ou sentimentos, na medida em que eles são de caráter moral ou valorativo. (...) juízos morais, sendo expressões de atitudes ou sentimentos, não são verdadeiros nem falsos; e acordos entre julgamentos morais não vão ser assegurados por nenhum método racional, pois não existe nenhum". (Maclntyre, 1985, p.12) 16 Ibidem, p.117.

17 Idem, p.119. Rawls, em seu $A$ theory of justice (1971), também compartilha desse horizonte liberal que desloca as concepções de bem para o âmbito do privado.
} 
para sua escolha e fundação, colocando-os então na esfera das emoções, do pré-racional, das decisões livres dos indivíduos.

Em relação ao individualismo liberal nietzschiano, MacIntyre o caracteriza a partir da figura do Übermensch, o super-homem nietzschiano. Este homem, o homem que transcende, não encontra seu bem em lugar algum do mundo social datado, "mas somente no que nele próprio dita sua própria nova lei e sua própria nova tábua de virtudes". ${ }^{18}$ Esse super-homem não encontra nenhum bem objetivo com autoridade sobre ele no mundo social datado porque ele é vazio no tocante às relações pessoais e atividades sociais. O Übermensch, a filosofia moral nietzschiana, está calcado num solipsismo moral, pois elabora uma visão do super-homem (great man), em sua obra $A$ vontade de potência (1951), isolado da sociabilidade, solitário. MacIntyre chega a transcrever parte de uma das notas (962):

Um super-homem (great man) - um homem cuja natureza construiu e inventou em grande estilo - o que ele é? (...) Se ele não pode conduzir, ele vai sozinho; então pode acontecer que rosnará a alguma coisa que encontra no caminho (...) ele não quer corações 'compreensivos', mas servos, ferramentas; no seu intercurso com os homens, ele é sempre solícito em criar casos com eles. Ele sabe que ele é incomunicável: ele os acha insípidos para poderem ser-lhes familiar; e quando alguém pensa que ele é, ele geralmente não é. Quando não falando para si mesmo, ele veste uma máscara. Ele antes mente do que fala a verdade: ele requer mais espírito e vontade. Há uma solidão dentro dele que é inacessível ao elogio ou ao medo, sua própria justiça está além do apelo. ${ }^{19}$

Essa solidão do super-homem (great man) faz com que ele só possa fundar a moral em si mesmo, na sua própria vontade, de ser a sua própria autoridade moral auto-suficiente, recusando qualquer heteronomia, num processo de auto-absorção. Esta caracterização do super-homem, segundo MacIntyre, é central para a argumentação nietzschiana de que "a moralidade da sociedade européia, desde a antiguidade na Grécia, não tem sido mais que

${ }_{18}$ Maclntyre, 1985, p.257.

${ }^{19}$ Apud Maclntyre, 1985, p.257. 
um conjunto de máscaras para a vontade de poder e que a pretensão à objetividade de tais moralidades não pode ser racionalmente sustentada". ${ }^{20}$ Pois o super-homem (great man) quando fala com os outros homens, é máscara pura, não se comunica, mente, exige vigor e vontade, nunca espírito racional. Daí que o conceito de super-homem (great man) ser, na visão de MacIntyre, um pseudo-conceito, por se colocar fora da sociabilidade e da racionalidade, representando a tentativa final do individualismo de escapar às suas próprias conseqüências. Ao querer ser uma alternativa viável à modernidade individualista liberal, de escapar à confusão instalada na linguagem da moralidade moderna - carregada de pseudo-conceitos como os de utilidade e direitos naturais - a posição nietzschiana é, ao contrário, o momento mais representativo do seu desenvolvimento interno. "A posição nietzschiana é somente mais uma faceta daquela mesma cultura moral da qual Nietzsche se assumiu como um crítico implacável”. ${ }^{21}$

Por fim, em sua obra Justiça de Quem? Qual Racionalidade? (1991), MacIntyre, ao caracterizar o perspectivismo moral, no confronto com o seu conceito de pesquisa racional constituída pela tradição e dela constitutiva, refere-se à Nietzsche, ao lado de Durkheim, como seus antecessores. Segundo ele, o perspectivismo está comprometido em manter que nenhuma reivindicação de verdade, feita em nome de qualquer uma das tradições culturais em competição na arena da sociedade, poderia preterir as reivindicações feitas em nome de seus oponentes, afirmando ser-lhes superior. Com isso, o perspectivismo supõe que "alguém poderia temporariamente adotar o ponto de vista de uma tradição, e, aí, trocá-lo por outro, como se troca de roupa, ou como se alguém pudesse ter um papel numa peça e, depois, um outro completamente diferente, numa peça também diferente". ${ }^{22}$

Contudo, para MacIntyre, o perspectivismo é uma doutrina que só é possível para aqueles que encarnam uma série sucessiva de papéis temporários. "De seu ponto de vista, todas as concepções da verdade, exceto a mais ínfima, parecem ter sido desacreditadas. (...) Portanto, a sua não é tanto um conclusão sobre a verdade, quanto uma exclusão dela e, dessa forma, do debate racional”. ${ }^{23} \mathrm{E}$ Nietzsche compreendeu isso muito bem, pois não se

\footnotetext{
20 Idem, p.258.

21 lbidem, p.258.

22 Maclntyre, 1991, p.394.

23 Idem, p.395.
} 
empenhou numa argumentação dialética com Sócrates, o que implicaria numa sujeição à tirania da razão.

Não se deve discutir com Sócrates, devemos ridicularizá-lo por sua feiúra e maus modos. Tal ridicularização, como resposta à dialética, é imposta nos parágrafos aforísticos de Götzen-Dammerung. (...) Um aforismo não é um argumento. Gilles Deleuze o chama de 'jogo de forças' (...), algo através do qual energia é transmitida, e não através do qual conclusões são alcançadas. ${ }^{24}$

Ou seja, o perspectivismo nietzschiano conduz à irracionalidade no âmbito da moralidade, reduzindo tudo a um jogo de forças e de máscaras que escondem estas forças.

Podemos, então, até aqui, resumir em três proposições básicas a leitura macintyreana de Nietzsche:

1. Nietzsche é um emotivista moral;

2. Nietzsche é o ápice do individualismo liberal;

3. Nietzsche é um perspectivista irracional.

Agora voltaremos nossa análise para o próprio Nietzsche, através de algumas de suas obras, e checar essas posições que lhe foram atribuídas por MacIntyre, com o concurso da interpretação de Eugen Fink. Mas convém antes ressaltar que MacIntyre não é um crítico puramente externo a Nietzsche, pois incorpora elementos teóricos deste em sua própria filosofia moral. Suas leituras de Nietzsche são marcadas, simultaneamente, pela admiração do seu diagnóstico crítico da moralidade moderna e pela recusa das alternativas propostas por ele como solução para o problema - Nietzsche é visto por ele como um moralista, não como mero negador de toda moralidade. O diagnóstico nietzschiano do fracasso da moralidade moderna é assumido quase na totalidade por MacIntyre, ou seja, ele não passa incólume pela leitura da obra de Nietzsche.

24 Ibidem, p.395. 


\section{A metaética nietzschiana: o fundamento estético-cosmológico}

A leitura de algumas das obras de Nietzsche seguirá o roteiro de explicitação de uma linha mestra, a nosso ver, de sua filosofia moral: uma concepção estético-cosmológica do mundo. Concepção essa que perpassa toda a sua obra, proporcionando-lhe o pano de fundo conceitual possibilitador da compreensão dos movimentos e contradições aparentes presentes nos seus escritos, como também de suas tematizações. Entretanto, vamos nos limitar àqueles elementos que irão proporcionar uma checagem das teses macintyreanas, que possa explicitar fundamentos para a crítica destas, problematizando-as.

\section{Uma cosmologia estética ou "metafísica do artista"}

Segundo Fink (1993), a rejeição por Nietzsche da metafísica e da filosofia tradicional não é fruto de uma perspectiva ontológica, por estas não colocarem o problema do ser de maneira verdadeira, mas moral, ou seja, Nietzsche vê a metafísica como uma corrente de vida em que se confirmam avaliações, um movimento que contém valores que atrofiam, oprimem e enfraquecem a vida. Ele coloca a metafísica na ética da vida:

Nietzsche não prova nem pesa as representações ontológicas da tradição metafísica por elas próprias, considera-as simplesmente como sintomas que indicam tendências da vida. Por outras palavras, ele não põe a questão do ser, pelo menos não da maneira como durante longos séculos a discutiram; o problema do Ser é recoberto pelo problema do valor. ${ }^{25}$

Daí porque só ser possível entender as categorias filosóficas nietzschianas a partir dessa sua convicção fundamental: a sua interpretação do ser como valor.

Em O nascimento da tragédia (1992), Nietzsche formula uma "metafísica do artista", onde o tema estético adquire a condição de um princípio ontológico fundamental, na ideia de que a existência do mundo só

${ }^{25}$ Fink, 1983, p.15. 
se justifica como fenômeno estético, onde já se explicita "um espírito que um dia (...) se porá contra a interpretação e a significação morais da existência"26 - essa moral que Nietzsche se refere é o cristianismo como "desde sempre a hostilidade à vida, a rancorosa, vingativa aversão contra a própria vida". ${ }^{27}$ Ao se perguntar pela natureza do trágico entre os gregos, Nietzsche, na verdade, formula uma visão fundamental do ser. No fenômeno trágico percebe a verdadeira natureza da realidade. A arte, a poesia trágica, torna-se para ele a chave que dá acesso à vida primordial do mundo.

O fenômeno da arte é colocado no centro: é nele e a partir dele que deciframos o mundo. (...) Só com os olhos da arte consegue o pensador mergulhar o seu olhar no coração do mundo. Mas é essencialmente a arte trágica, a tragédia antiga, que possui este olhar penetrante. ${ }^{28}$

A arte trágica apreende a vida trágica do mundo, "o mundo, a cada instante a alcançada redenção de Deus, o mundo como a eternamente cambiante, eternamente nova visão do ser mais sofredor, mais antitético, mais contraditório, que só na aparência sabe redimir-se". ${ }^{29}$ No mundo trágico, a redenção não é entendida no sentido cristão do termo, mas na aceitação de que "há apenas a lei inexorável do declínio de tudo aquilo que surgiu do fundo do ser na existência individualizada, daquilo que se separou da corrente da vida universal", ${ }^{30}$ onde se encontram confundidas vida e morte, ascensão e decadência de tudo o que é finito. O sentido trágico da existência é

um sentido de artista e um retro-sentido de artista por trás de todo acontecer - um "Deus", se assim se deseja, mas decerto só um deus-artista completamente inconsiderado e amoral, que no construir como no destruir, no bom como no ruim, quer aperceber-se de seu idêntico prazer e autocracia, que, criando mundos, se desembaraça da necessidade da

\footnotetext{
${ }^{26}$ Nietzsche, 1992, p.19.

27 Idem, p.25.

${ }^{28}$ Fink, 1983, p.18.

${ }^{29}$ Nietzsche, 1992, p.18.

30 Fink, 1983, p.18.
} 
abundância e superabundância do sofrimento das contradições nele apinhadas. ${ }^{31}$

A aceitação trágica do declínio da própria existência, a aceitação do horrível e do medonho que há nela, é fruto do conhecimento de que todas as formas finitas são apenas ondas temporárias na grande maré da vida, pois o declínio do finito não é destruição pura e simples, mas regresso ao fundo primordial da vida de onde surgiram todas as coisas individualizadas, ou seja, tudo é uno. Na tragédia grega Nietzsche descobre

a oposição da forma e da maré amorfa da vida, de peras e apeíron; do existente finito, o qual, votado à destruição, reverte para o mundo infinito, e deste próprio fundo que constantemente faz surgir de si formas - a esta oposição dá ele mesmo o nome de oposição entre o apolíneo e o dionisíaco. ${ }^{32}$

O trágico é, então, compreendido como princípio cósmico, ou seja, uma compreensão do mundo, uma cosmologia. ${ }^{33}$

Para Nietzsche, o desenvolvimento da arte está ligado à "duplicidade do apolíneo e do dionisíaco, da mesma maneira como a procriação depende da dualidade dos sexos, em que a luta é incessante e onde intervêm periódicas reconciliações". ${ }^{34}$ São dois impulsos, os universos artísticos do sonho e da embriaguez. Apolo simboliza o grande plasmador de formas, o instinto plástico, o deus dos poderes configuratórios, a divindade da luz, "aquela limitação mensurada, aquela liberdade em face das emoções mais selvagens, aquela sapiente tranquilidade do deus plasmador". ${ }^{35}$

Apolo é o principium individuationis, que em meio a um mundo de tormentos dá o sentido de individualidade às coisas, "a partir de cujos gestos e olhares nos falam todo o prazer e toda a sabedoria da 'aparência', juntamente com a sua beleza". ${ }^{36}$ Quem nunca já exclamou alguma vez nos seus sonhos: “É um sonho! Quero continuar a sonhá-lo!”? - a necessidade da

\footnotetext{
31 Nietzsche, 1992, p.18.

32 Fink, 1993, p.18-9.

${ }^{33}$ Sobre a cosmologia em Nietzsche e sua conexão com os valores, ver Marton (2010b).

34 Nietzsche, 1992, p.27.

35 Idem, p.29.

36 Ibidem, p.30.
} 
experiência onírica que torna a vida possível e digna de ser vivida. Dionísio é o deus do caótico, do desmedido,

o terror que se apodera do ser humano quando, de repente, é transviado pelas formas cognitivas da aparência fenomenal, na medida em que o princípio da razão, em algumas de suas configurações, parece sofrer uma exceção. Se a esse terror acrescentarmos o delicioso êxtase que, à ruptura do principium individuationis ascende do fundo mais último do homem, sim, da natureza, ser-nos-á dado lançar um olhar à essência do dionisíaco, que é trazido a nós, o mais de perto possível, pela analogia da embriaguez. ${ }^{37}$

Apolo e Dionísio são como poderes artísticos que, sem a mediação do artista, irrompem da própria natureza, e nos quais os impulsos artísticos desta se satisfazem imediatamente e por via direta:

por um lado, como o mundo figural do sonho, cuja perfeição independe de qualquer conexão com a altitude intelectual ou educação artística do indivíduo, por outro, como realidade inebriante que novamente não leva em conta o indivíduo, mas procura inclusive destruí-lo e libertá-lo por meio de um sentimento místico de unidade. ${ }^{38}$

Apolo é o poder do ser, o sonho produtor de formas e imagens, criador da aparição. A individuação, a separação, é uma enganadora imagem apolínea, pois "toda a vida repousa sobre a aparência, a arte, a ilusão, a óptica, a necessidade do perspectivístico e do erro" ${ }^{39}$ Dionísio, a embriaguez, é a torrente cósmica, o devir primordial que despedaça e reabsorve todas as formas, que suprime tudo que é finito e individual.

Sob a magia do dionisíaco torna a selar-se não apenas o laço de pessoa a pessoa, mas também a natureza alheada, inamistosa ou subjugada volta a celebrar a festa de

\footnotetext{
37 Idem, p.30.

38 Ibidem, p.32.

39 Idem, p.19.
} 
reconciliação com seu filho perdido, o homem. (...) Agora, graças ao evangelho da harmonia universal, cada qual se sente não só unificado, conciliado, fundido com o seu próximo, mas um só, como se o véu de Maia tivesse sido rasgado e, reduzido a tiras, esvoaçasse diante do misterioso unoprimordial. $^{40}$

Daí ser $O$ nascimento da tragédia uma cosmologia estética ou uma "metafísica do artista", "uma interpretação do todo universal que segue o fio condutor da arte; na arte manifesta-se igualmente as duas forças fundamentais do ser que combatem entre si”. ${ }^{41}$

Contudo, Nietzsche não as vê como realidades independentes, o apolíneo contraria o dionisíaco e vice-versa, combatem-se, mas um não pode existir sem o outro.

O servidor ditirâmbico de Dionísio só é, portanto, entendido por seus iguais! Com um assombro devia mirá-lo o grego apolíneo! Como um assombro que era tanto maior quanto em seu íntimo se lhe misturava o temor de que, afinal, aquilo tudo não lhe era na realidade tão estranho, que sua consciência apolínea apenas lhe cobria como um véu esse mundo dionisíaco. ${ }^{42}$

Para isso, basta demolirmos o artístico edifício da cultura apolínea, a fim de vislumbrarmos os fundamentos nos quais se assenta: o dionisíaco.

O grego conheceu e sentiu os temores e os horrores do existir; para que lhe fosse possível de algum modo viver, teve de colocar ali, entre ele e a vida, a resplendente criação onírica dos deuses olímpicos. (...) O mesmo impulso que chama a arte à vida, como a complementação e o perfeito remate da existência que seduz a continuar vivendo, permite também

40 lbidem, p.31.

41 Fink, 1983, p.25.

42 Nietzsche, 1992, p.35. 
que se constitua o mundo olímpico, no qual a 'vontade' helênica colocou diante de si um espelho transfigurador. ${ }^{43}$

Por detrás das formas apolíneas, da cultura científica, do indivíduo e da medida - Apolo é a divindade ética, exige dos seus a medida, o autoconhecimento - há o desmesurado, a auto-exaltação, a era dos Titãs e do mundo extra-apolíneo, ou seja, o mundo dos bárbaros. Para o grego apolíneo, "titânico" e "bárbaro" são efeitos do dionisíaco. "Sem isso, contudo, poder dissimular a si mesmo que ele próprio apesar de tudo, era ao mesmo tempo aparentado interiormente àqueles titãs e heróis abatidos". ${ }^{4}$ Daí, para Nietzsche, que a aparência, efeito apolíneo, não ser mais que a contraparte necessária do fundo primordial dionisíaco:

Com efeito, quanto mais percebo na natureza aqueles onipotentes impulsos artísticos e neles um poderoso anelo pela aparência, pela redenção através da aparência, tanto mais me sinto impelido à suposição metafísica de que o verdadeiramente-existente e uno-primordial, enquanto o eterno-padecente e pleno de contradição necessita, para sua constante redenção, também da visão extasiante, da aparência prazerosa - aparência esta que nós, inteiramente envolvidos nela e dela consistentes, somos obrigados a sentir como o verdadeiramente não-existente, isto é, como um ininterrupto vir-a-ser no tempo, espaço e causalidade, em outros termos, como realidade empírica. ${ }^{45}$

A própria atividade artística humana, na perspectiva trágica de Nietzsche, expressa essa unidade entre o apolíneo e o dionisíaco. O verdadeiro sujeito da arte não é o homem que julga exercê-la, mas o próprio fundamento do mundo que age através do homem, que faz dele o receptáculo de sua tendência.

O próprio fundamento do mundo procuraria a 'redenção' da irrequietação vertiginosa, da avidez, do sofrimento da

${ }^{43}$ Idem, p.37.

44 Ibidem, p. 41.

45 Idem, p.39. 
'vontade' irrequieta, justamente na ilusão da aparência bela, na aparente eternidade da plástica, na estabilidade da forma, na harmonia exata das coisas. ${ }^{46}$

Pois na medida em que o sujeito é um artista, o gênio artístico, ele já está liberto de sua vontade individual e torna-se um medium através do qual o verdadeiramente existente celebra sua redenção na aparência apolínea.

Acima de tudo, para a nossa degradação e exaltação, uma coisa nos deve ficar clara, a de que toda a comédia da arte não é absolutamente representada por nossa causa, para a nossa melhoria e educação, tampouco que somos os efetivos criadores desse mundo da arte: mas devemos sim, por nós mesmos, aceitar que já somos, para o verdadeiro criador desse mundo, imagens e projeções artísticas, e que nossa suprema dignidade temo-la no nosso significado de obras de arte - pois só como fenômeno estético podem a existência e o mundo justificar-se eternamente. $^{47}$

Com isso, a própria atividade artística do homem é interpretada como um acontecimento cósmico. $\mathrm{Na}$ arte trágica grega se encontram expressas a suprema união e interpenetração do dionisíaco e do apolíneo, onde o fundo original dionisíaco projeta-se continuamente na aparência e encontra na arte a transfiguração da aparição no acontecer. Só a arte tem o poder de "transformar aqueles pensamentos enojados sobre o horror e o absurdo da existência em representações com as quais é possível viver: são elas o sublime, enquanto domesticação artística do horrível e o cômico, enquanto descarga artística da náusea do absurdo". ${ }^{48} \mathrm{O}$ próprio Nietzsche resume, então, os ensinamentos da tragédia grega que, na verdade, são os elementos básicos de sua cosmologia estética ou "metafísica do artista": "o conhecimento básico da unidade de tudo o que existe, a consideração da individuação como causa primeira do mal, a arte como a esperança jubilosa de que possa ser rompido o feitiço da individuação, como prosseguimento de uma unidade

\footnotetext{
${ }^{46}$ Fink, 1983, p.26.

${ }^{47}$ Nietzsche, 1992, p.47.

48 Idem, p.56.
} 
restabelecida". 49 Nesse sentido, Nietzsche nos oferece uma interpretação do mundo, propõe-nos uma estrutura fundamental do existente em geral, a partir do conceito do fundo dionisíaco primordial e da arte trágica como instância que nos acessa à ele.

A difícil relação entre o apolíneo e o dionisíaco na tragédia poderia ser realmente simbolizada através de uma aliança fraterna entre as duas divindades: Dionísio fala a linguagem de Apolo, mas Apolo, ao fim, fala a linguagem de Dionísio: com o que fica alcançada a nota suprema da tragédia e da arte em geral..$^{50}$

Em Verdade e mentira no sentido extra-moral, Nietzsche não avalia a verdade e a mentira da perspectiva moral, mas da totalidade do mundo. Trata-se do papel do intelecto na apreensão da realidade verdadeira, de avaliála a partir de sua visão estética da realidade primordial do devir, do unoprimordial dionisíaco. A capacidade humana de conhecer, para ele, é fugaz e fantasmagórica, sem finalidade e gratuita, quando observada dentro da natureza:

Em algum remoto rincão do universo cintilante que se
derrama em um sem número de sistemas solares, havia uma
vez um astro, em que animais inteligentes inventaram o
conhecimento. Foi o minuto mais soberbo e mais mentiroso
da 'história universal': mas também foi somente um minuto.
Passados poucos fôlegos da natureza, congelou-se o astro, e os
animais inteligentes tiveram de morrer.

A pequenez do conhecimento é tão grande que houve eternidades em que ele não estava e quando ele tiver passado nada terá acontecido, que não há para o intelecto humano nenhuma missão que vá além da vida humana. A função do conhecimento humano é apenas a de um meio auxiliar aos mais infelizes, delicados e perecíveis dos seres: os homens. A força do intelecto, sua natureza mais própria é o disfarce:

\footnotetext{
49 Ibidem, p.70.

50 Idem, p.130.

51 Nietzsche, 1983, p.45.
} 
é o meio pelo qual os indivíduos mais fracos, menos robustos, se conservam, aqueles aos quais está vedado travar uma luta pela existência com chifres ou presas aguçadas. No engenho, o lisonjear, o mentir e ludibriar, o falar-por-trás-das-costas, o representar, o viver em glória de empréstimo, o mascarar-se, a convenção dissimulante, o jogo teatral diante de outros e diante de si mesmo, em suma, o constante bater de asas em torno dessa única chama que é a vaidade, é a tal ponto a regra e a lei que quase nada é mais inconcebível do que como pode aparecer entre os homens um honesto e puro impulso à verdade. $^{52}$

Se o efeito mais geral do conhecimento é o engano, de onde viria, então, esse impulso à verdade? Para Nietzsche, o instinto de verdade nasceu do instinto de fingimento, da própria natureza de disfarce que é o conhecimento humano.

A linguagem nasce da necessidade do homem pôr fim à guerra natural de todos contra todos, quando o homem faz um acordo de paz, fixando aquilo que deve ser "verdade", isto é, "é descoberta uma designação uniformemente válida e obrigatória das coisas, e a legislação da linguagem dá também as primeiras leis da verdade: pois surge pela primeira vez o contraste entre verdade e mentira" (Ibidem, p.46). A linguagem é, portanto, um conjunto de convenções, de denominações que passam a ser válidas. As designações e as coisas não se recobrem, a linguagem não é a expressão adequada de todas as realidades.

Somente por esquecimento pode o homem alguma vez chegar a supor que possui uma "verdade" (...). Se ele não quiser contentar-se com a verdade na forma de tautologia, isto é, com estojos vazios, comprará certamente ilusões por verdade. $^{53}$

Ou seja, não há um vínculo lógico entre as coisas, a realidade, e a linguagem, suas designações. Para Nietzsche,

52 Idem, p.45.

53 Ibidem, p.47. 
Acreditamos saber algo das coisas mesmas, se falamos de árvores, cores, neves e flores, e no entanto não possuimos nada mais do que metáforas das coisas, que de nenhum modo correspondem às entidades de origem. (...) Em todo caso, portanto, não é logicamente que ocorre a gênese da linguagem, e o material inteiro, no qual e com o qual mais tarde o homem da verdade, o pesquisador, o filósofo, trabalha e constrói, provém, se não da Cucolândia das Nuvens, em todo caso não da essência das coisas. ${ }^{54}$

A verdade é, então, na já clássica caracterização nietzschiana, nada mais que

um batalhão móvel de metáforas, metonímias, antropomorfismos, enfim, uma soma de relações humanas, que foram enfatizadas poética e retoricamente, transpostas, enfeitadas, e que, após longo uso, parecem a um povo sólidas, canônicas e obrigatórias: as verdades são ilusões, das quais se esqueceu que o são, metáforas que se tornaram gastas e sem força sensível, moedas que perderam sua efígie e agora só entram em consideração como metal, não mais como moedas. ${ }^{55}$

Ou seja, a mentira da linguagem, a mentira dos conceitos, mentira tomada no sentido extra-moral do termo, reside nesse seu esquecimento de serem ilusões. Nietzsche completa, então, o raciocínio:

Ora, o homem esquece sem dúvida que é assim que se passa com ele: mente, pois, de maneira designada, inconscientemente e segundo hábitos seculares - e justamente por essa inconsciência, justamente por esse esquecimento, chega ao sentimento da verdade. ${ }^{56}$

As verdades são ilusões que o homem esqueceu que eram ilusões, daí que a inconsciência no uso das palavras e conceitos, o esquecimento do

54 Idem, p.47-8.

55 Ibidem, p.48.

56 Idem, p.49. 
caráter problemático de sua formação, é a condição de uma vontade honesta e científica de verdade. Sua "mentira" no sentimento de verdade, segundo Nietzsche,

coloca agora seu agir como ser "racional" sob a regência das abstrações, não suporta mais ser arrastado pelas impressões súbitas, pelas intuições, universaliza antes todas essas impressões em conceitos mais descoloridos, mais frios, para atrelar a eles o carro de seu viver e agir. ${ }^{57}$

$\mathrm{Na}$ concepção de Nietzsche, a vontade de verdade é um resíduo do confronto, originalmente estético, do homem com o mundo cintilante, uma expressão do elemento apolíneo que não quer se reconhecer no fundamento dionisíaco do mundo; uma confrontação que se verificou na imagem física, nas metáforas intuitivas individuais. Quando uma verdade é trazida à luz, ela é de valor limitado, isto é, de natureza antropomórfica e não contém nada que seja verdadeiro em si, efetivo e universalmente válido, sem levar em conta o homem.

O pesquisador destas verdades procura, no fundo, apenas a metamorfose do mundo em homem, luta por um entendimento do mundo como uma coisa à semelhança do homem e conquista, no melhor dos casos, o sentimento de uma assimilação. (...) Seu procedimento consiste em tomar o homem por medida de todas as coisas no que, porém, parte do erro de acreditar que temos essas coisas imediatamente, como objetos puros diante de si. Esquece, pois, as metáforas intuitivas de origem, como metáforas, e as toma pelas coisas mesmas. ${ }^{58}$

Para Nietzsche, o mundo da ciência, dos conceitos abstratos, só é possível mediante o esquecimento do mundo primevo das metáforas, pela petrificação da torrente primordial da massa de imagens oriundas da capacidade originária da fantasia humana, de sua dimensão apolínea forjadora de formas, ou seja, a "mentira" da ciência reside justamente no fato

57 Ibidem, p.49.

58 Idem, p.50. 
de que o homem esquece de si mesmo como sujeito, como sujeito artisticamente criador. Para ele, a percepção correta, ou seja, a expressão adequada de um objeto no sujeito, parece um absurdo cheio de contradições,

posto que entre duas esferas absolutamente distintas, como o são o sujeito e o objeto, não há nenhuma causalidade, nenhuma exatidão, nenhuma expressão, mas, no máximo, uma relação estética, quer dizer: um extrapolar alusivo, um traduzir balbuciante a uma linguagem completamente estranha - para o que, em todo caso, se necessita de uma esfera intermediária e uma força mediadora livremente inventivas. ${ }^{59}$

Na sua essência, a atividade científica é o esquecimento de si enquanto atividade artística humana, é a mentira que não se percebe como mentira no sentido extra-moral -, a cultura apolínea exacerbada e esquecida do seu fundo dionisíaco primordial.

Esse impulso para a construção de metáforas é fundamental para o homem, sem ele o homem mesmo não seria levado em conta, perde sua condição de homem. Contudo, o edifício da ciência não consegue dominar esse impulso, "quando se constrói para ele, a partir de suas criaturas liquefeitas, os conceitos, um novo mundo regular e rígido como uma praça forte, nem por isso, na verdade, ele é subjugado e mal é refreado" ${ }^{60}$ Segundo Nietzsche, ele procura atuar em outros espaços, se expressa em outros marcos para além da ciência: o mito e, em geral, a arte.

Constantemente ele embaralha as rubricas e compartimentos dos conceitos, propondo novas transposições, metáforas, metonímias, constantemente ele mostra o desejo de dar ao mundo de que dispõe o homem acordado uma forma tão cromaticamente irregular, inconsequentemente incoerente, estimulante e eternamente nova como a do mundo do sonho. ${ }^{61}$

\footnotetext{
${ }^{59}$ Nietzsche, 2006, p.119.

60 Nietzsche, 1983, p.50.

61 Idem, p.50.
} 
É como se o fundo primordial dionisíaco, o devir eterno do mundo, se recusasse a ser dominado nas formas apolíneas exacerbadas do mundo da ciência, e buscasse o mito e a arte, especialmente a arte trágica, como a expressão de seu movimento, a fim de que a própria existência humana não se perca no absurdo e se justifique esteticamente.

Nietzsche contrapõe ao homem científico, que já não detecta a mentira dos conceitos, o homem intuitivo, artístico; um refugiou-se na cápsula, considera os conceitos como a própria essência das coisas, ao passo que o outro conhece o engano de todas as determinações, incluindo o das metáforas, embora se mova livremente perante a realidade, criativamente, formando imagens. ${ }^{62}$

Daí, para Nietzsche, o artista, o homem intuitivo, ser um tipo superior em relação ao homem lógico, o cientista. Ele é um intelecto que se tornou livre, que desmantela, entrecruza e recompõe ironicamente o arcabouço da ciência, ele não é guiado por conceitos, mas por intuições.

Dessas intuições nenhum caminho regular leva à terra dos esquemas fantasmagóricos, das abstrações: para elas não foi feita a palavra, o homem emudece quando as vê, ou fala puramente em metáforas proibidas e em arranjos inéditos de conceitos, para pelo menos através da demolição e escarnecimento dos antigos limites conceituais corresponder criativamente à impressão da poderosa intuição presente. ${ }^{63}$

É no homem intuitivo que se expressa uma vida justificada esteticamente, onde o dionisíaco não é negado pela exasperação apolínea da razão, onde a mentira da ciência se desvanece pela vida da arte. Em Nietzsche, "a arte surge-lhe como o verdadeiro organon da filosofia porque o próprio fundo primordial do ser desempenha, ao criar o mundo, o papel do 'artista primordial'". ${ }^{64}$ Daí a preferência nietzschiana por esse homem intuitivo:

\footnotetext{
62 Fink, 1983, p.39.

${ }^{63}$ Nietzsche, 1983, p.51.

64 Fink, 1983, p.35.
} 
onde alguma vez o homem intuitivo, digamos como na Grécia antiga, conduz suas armas mais poderosamente e mais vitoriosamente do que seu reverso, pode configurar-se, em caso favorável, uma civilização e fundar-se o domínio da arte sobre a vida: aquele disfarce, aquela recusa da indigência, aquele esplendor das intuições metafóricas e em geral aquela imediatez da ilusão acompanham todas as manifestações de tal vida. ${ }^{65}$

É no homem intuitivo que o apolíneo e o dionisíaco falam a mesma linguagem, não se instalando a "mentira" da ciência.

\section{0 procedimento genealógico: o valor dos valores}

Para Nietzsche, todos os problemas da filosofia são problemas de valor. Uma preocupação central que atravessa sua obra é a dos valores morais. E isso ele próprio nos revela:

Dada minha peculiar inclinação em insistir sobre certos problemas, inclinação que eu confesso a desgosto - pois se refere à moral, a tudo o que até agora se enalteceu na terra como moral - (...) que quase teria direito a chamar-lhe meu a priori, - tanto minha curiosidade como minhas suspeitas tiveram que deter-se prematuramente na pergunta sobre que origem tem propriamente nosso bem e nosso mal. (...) Algo da escolaridade histórica e filológica, (...) transmudou logo meu problema neste outro: sob que condições inventou-se o homem aqueles juízos de valor, bom e mal? E que valor têm eles mesmos? ${ }^{66}$

Sua reflexão em torno dos valores morais se faz permeada pela perspectiva da transvaloração dos valores. Seu projeto genealógico busca operar uma subversão crítica: pôr a questão do valor dos valores e esta, ao ser colocada, levanta a pergunta pela criação dos valores.

65 Nietzsche, 1983, p.52.

${ }^{66}$ Nietzsche, 1990, p.19-20. 
Se até agora não se pôs em causa o valor dos valores "bem" $e$ "mal", é porque se supôs que existiram desde sempre, instituídos num além, encontravam legitimidade num mundo supra-sensível. No entanto, uma vez questionados, revelam-se apenas "humanos, demasiado humanos"; em algum momento e em algum lugar, simplesmente foram criados. ${ }^{67}$

Esta é a tarefa crítica que Nietzsche se propõe:

Necessitamos uma crítica dos valores morais, devemos alguma vez pôr em questão o valor mesmo desses valores - e para isto se necessita ter conhecimento das condições e circunstâncias nas quais surgiram, em que se desenvolveram e se modificaram (a moral como consequencia, como sintoma, máscara, tartufaria, medicina, estímulo, empecilho ou veneno), um conhecimento que até agora não existiu nem tampouco sequer se o desejou. ${ }^{68}$

No tratado primeiro da Genealogia da Moral (1990), Nietzsche faz uso do procedimento genealógico para trazer à luz a origem da inversão dos valores produzida pelo cristianismo, com isso estabelece uma nítida distinção entre a moral do escravo e a moral do nobre ou senhor. Critica os psicólogos ingleses por atribuírem a origem dos conceitos de bem e mal ao esquecimento e ao hábito. Falta-lhes o espírito histórico para ir até a gênese profunda dos valores morais. Ele observa que o juízo "bom” não procede daqueles que a quem se dispensa "bondade", mas sim foram os próprios "bons", ou seja, os nobres, os poderosos, os homens de posição superior e de elevados sentimentos que se sentiram e se valoraram a si mesmos e à suas ações como boas, ou seja, como algo de nível superior, em contraposição a tudo o que é baixo, abjeto, vulgar e plebeu.

Partindo deste pathos da distância é que se arrogaram o direito de criar valores, de cunhar nomes de valores. (...) O pathos da nobreza e da distância, como dissemos, o duradouro e dominante sentimento global e radical de uma

${ }^{67}$ Marton, 1993, p.50.

68 Nietzsche, 1990, p.23. 
espécie superior dominadora em sua relação com uma espécie inferior, com um "embaixo" - esta é a origem da antítese "bom" e "mal". 69

Para sua tese, ele encontra reforço na observação de que em todas as línguas designações de "bom" remetem a idênticas metamorfoses conceituais:

que, em todas as partes, "nobre", "aristocrático" no sentido estamental, é o conceito básico a partir do qual se desenvolve. Logo, por necessidade, "bom" no sentido de "psiquicamente nobre", de "aristocrático", de "psiquicamente de índole elevada", "psiquicamente privilegiado"; um desenvolvimento que marcha sempre paralelo àquele outro que faz com que "vulgar", "plebeu", "baixo", acabem por passar ao conceito "mau". 70

Por exemplo, a palavra "mau" (schlecht), significou originariamente o "simples", o homem vulgar e baixo; inversamente, o conceito "bom" (gut) se referia ao homem de nível superior, ao nobre, ao poderoso, ao senhor. Daí que, para Nietzsche, comprovar-se que nas palavras e raízes que designam "bom" aparece, de muitas formas, o matiz básico em razão dos quais os nobres se sentiam precisamente homens de nível superior. As valorações brotavam, portanto, de uma forma de ser, de uma forma de encontrar-se na vida e na sociedade.

Nietzsche, então, distingue claramente a moral do nobre ou senhor da moral do escravo, a partir da figura do sacerdote, figura-mor desta última. A casta sacerdotal é a degeneração e, mais tarde, a antítese da casta cavalheiresca e aristocrática.

Desde o começo há algo não sadio em tais aristocracias sacerdotais e nos hábitos neles dominantes, hábitos separados da atividade, hábitos em parte dedicados a incubar ideias e em parte explosivos em seus sentimentos, e que tem como sequela

69 Idem, p.31-2.

$70 \mathrm{lbidem}$, p.33. 
aquela debilidade e aquela neurastenia intestinais que atacam quase de modo inevitável aos sacerdotes de todas as épocas. ${ }^{71}$

Mas o remédio que inventaram para curar sua doença foi mais perigoso que a própria doença: os sacerdotes inventaram a religião, inventaram a metafísica hostil aos sentidos, inventaram o "outro mundo", o além. A partir de sua forma de valorar a alma humana adquiriu alguma profundidade e se tornou interessante, entretanto também se tornou ruim (böse). Eles se tornaram, segundo Nietzsche, a antítese da casta nobre quando foram por ela destronados, e passaram a mobilizar contra ela todos os fracos, os falhos e sofredores, invertendo todos os valores aristocráticos.

Os juízos de valor cavalheiros-aristocráticos têm como pressuposto uma constituição física poderosa, uma saúde florescente, rica, inclusive transbordante, junto com o que condiciona a manutenção da mesma, ou seja, a guerra, as aventuras, a caça, a dança, as lutas e, em geral, tudo o que a atividade forte, livre, alegre leva consigo. ${ }^{72}$

A maneira sacerdotal de valorar, ao contrário, tem outros pressupostos, pois as coisas vão mal para eles quando há a guerra.

Os sacerdotes são, como é sabido, os inimigos mais ruins porquê? Porque são os mais impotentes. Por causa dessa impotência o ódio cresce neles até converter-se em algo monstruoso e sinistro, no mais espiritual e mais venenoso. (....) Comparado com o espírito de vingança sacerdotal, não conta nenhum outro espírito. ${ }^{73}$

Nietzsche vê nos judeus o representante histórico típico dessa moral sacerdotal, a encarnação da sede de vingança que produziu a inversão dos valores nobres, o seu ressentimento como a fonte da nova valoração. "Os judeus, esse povo sacerdotal, que, por não saberem tomar a satisfação de seus inimigos e dominadores, o fizeram com uma radical transvaloração dos

\footnotetext{
71 Idem, p.37.

72 Ibidem, p.38.

73 Idem, p.39.
} 
valores próprios destes, ou seja, por um ato de vingança mais espirituaP’ (Idem, p.39). Daí porque eles terem levado a termo a inversão da identificação aristocrática dos valores $($ bom $=$ nobre $=$ poderoso $=$ belo $=$ feliz $=$ amado de deus) e a mantiveram com o ódio mais profundo, o da impotência, ou seja,

os miseráveis são os bons; os pobres, os impotentes, os baixos são os únicos bons; os que sofrem, os indigentes, os enfermos, os disformes são também os únicos piedosos, os únicos benditos de deu, unicamente para eles existe a bemaventurança - ao contrário, vós, vós os nobres e os violentos, vós sois por toda a eternidade, os maus, os cruéis, os lascivos, os insaciáveis, os ateus, e vós sereis também eternamente os desventurados, os malditos e condenados! ${ }^{74}$

Assim, com os judeus começou a rebelião dos escravos na moral, quando o ressentimento se tornou ele próprio causador e gerador de valores; o ressentimento daqueles seres que estão vedados à autêntica reação, a reação da ação, e que só se livram dela com uma vingança imaginária. "Enquanto toda moral nobre nasce de um triunfante sim dito a si mesmo, a moral dos escravos diz não, já de antemão, a um 'fora', a um 'outro', a um 'não-eu'; e esse não é o que constitui sua ação criadora". ${ }^{75} \mathrm{O}$ escravo, o ressentido, o fraco, concebe primeiro a ideia de "mau", com que designa os nobres, os corajosos, os mais fortes que ele; a partir daí é que chega, antiteticamente, à concepção de "bom" que atribui a si mesmo. Do ponto de vista do forte, "ruim" é apenas uma criação secundária, enquanto para o fraco "mau" é a criação primeira, o ato fundador da sua moral.

O fraco só consegue afirmar-se negando aquele a quem não se pode igualar. Negação e oposição: essa é a lógica da moral do ressentimento. Aqui a força e a maldade se confundem. Radicalmente diferente, a moral dos nobres surge da afirmação e, mais, da autoafirmação. ${ }^{76}$

\footnotetext{
74 Ibidem, p.39-40.

75 Idem, p.43.

${ }^{76}$ Marton, 1993, p.53.
} 
Dessa forma, a inversão dos valores consiste em que agora se chama mau ao que antes era o bom, agora se chama mau ao poderoso, ao violento, ao cheio de vida. Inversamente, se chama bom o que era ruim, isto é, o homem baixo, simples e indigente, o enfermo.

O cristianismo é o herdeiro dessa transvaloração moral realizada pelo povo judeu, é o herdeiro da rebelião dos escravos na moral, pois não é a religião do amor, mas do ódio mais profundo contra os bons - isto é, os nobres, os poderosos, os verazes. ${ }^{77}$ Transformou o homem superior - um animal de rapina, a magnífica "besta loira", que vagabundeia cobiçosa de botins e de vitórias, e que habita no fundo de todas as raças nobres - em um animal manso, civilizado, um animal domesticado. O cristianismo redimiu o gênero humano dos senhores, do medo ao homem, a fazer com que o homem manso, domesticado, "o incuravelmente medíocre e desagradável tenha a sentir a si mesmo como a meta e o cume, como sentido da história, como 'homem superior'” ${ }^{78}$ Com isso, segundo Nietzsche,

hoje não vemos nada que aspire a ser maior, uma vez que descemos cada vez mais baixo, mais baixo, para algo mais débil, mais manso, mais pungente, mais plácido, mais medíocre, mais indiferente, mais cristão - o homem, não há dúvida, se tornou cada vez "melhor" ... Justo nisso reside a fatalidade da Europa - ao perder o medo do homem perdemos também o amor a ele, o respeito a ele, a esperança nele, mais ainda, a vontade dele. ${ }^{79}$

O cristianismo é, então, esse niilismo, ${ }^{80}$ esse estar cansado do homem, seu apequenamento e nivelamento por baixo. O cristianismo, na sua maneira de valorar ressentida, julga os homens pelos seus atos, como se lhes fosse possível escolher agir de um modo ou de outro. Mas para o forte não há

\footnotetext{
${ }_{77}$ Aqui é salutar lembrar o alerta de Marton (2010) de que Nietzsche "estabelece a diferença entre a figura histórica de Jesus e a institucionalização do cristianismo. Criação do apóstolo Paulo, a religião cristã veio impor o reino dos fracos e dos oprimidos. (...) Não está a bradar o seu grito de vitória contra uma doutrina que julga falsa. Bem ao contrário, procura alertar para um problema que se faz premente: 0 dos valores que há dois mil anos norteiam a conduta dos seres humanos, valores que desprezam 0 corpo, a vida, a Terra" (p.64-65).

78 Nietzsche, 1990, p.49.

79 Idem, p. 50.

80 Sobre o nillismo, ver Volpi (1999).
} 
escolha, ele tem de extravasar a sua força: "Exigir da fortaleza que não seja um querer-dominar, um querer-subjugar, um querer assenhorear-se, uma sede de inimigos e de resistência e de triunfos, é tão absurdo como exigir que a debilidade se exteriorize como fortaleza" ${ }^{81}$ A força simplesmente efetiva-se, é um efetivar-se, ela não pode deixar de exercer-se. A maneira nobre de avaliar ressalta o sentimento da plenitude e excesso da própria força. $O$ nobre não necessita, enquanto forte, de aprovação e dispensa qualquer termo de comparação, sabe-se criador de valores. $\mathrm{O}$ ressentimento do cristianismo opera uma inversão tal que, incapaz de admirar o forte, acusa-o de ser forte, de cometer o erro de ser forte. E esse modo de valorar do ressentido, do plebeu, do fraco, foi historicamente o vencedor, pelo menos até aquele momento, para Nietzsche.

No tratado segundo da Genealogia da Moral, Nietzsche mostra como esse processo de inversão dos valores pelos fracos tem uma de suas fontes na constituição da consciência moral ou interiorização da alma humana. A “interioridade” é uma perversão dos instintos:

todos os instintos que não se desafogam para fora se voltam para dentro - isto é o que se chamou a interiorização do homem: unicamente com isto se desenvolve nele o que mais tarde se denomina "alma". Todo o mundo interior, originariamente delgado, como que encerrado entre duas peles, foi separando-se e crescendo, foi adquirindo profundidade, largura, altura, na medida em que o desafogo do homem para fora foi ficando inibido. 82

Com isso, se desenvolve, na ótica nietzschiana, a má-consciência, já que os instintos de liberdade do homem foram podados, impedidos de se manifestar. "A inimizade, a crueldade, o prazer na perseguição - tudo isto voltou-se contra o portador de tais instintos: essa é a origem da 'máconsciência'”. ${ }^{83}$ A má-consciência como fruto da vingança dos ressentidos, de sua vitória sobre a vida, sobre o vigor dos nobres e de seu modo de valorar. Para Nietzsche, a consciência moral nada mais é do que a tentativa de negar

\footnotetext{
${ }^{81}$ Nietzsche, 1990, p.51.

82 Idem, p.96.

83 Ibidem, p.96.
} 
o instinto de crueldade que está presente na natureza do homem, como o subsolo camuflado da civilização humana. A crueldade

parece-lhe fazer parte integrante da natureza humana, afigurase-lhe ser um instinto fundamental, um prazer em contemplar o mal e de o provocar. E este prazer seria um ingrediente da alegria dos povos mais fortes e mais antigos. Para Nietzsche, o instinto de crueldade esconde-se ainda na prática primitiva dos povos civilizados. ${ }^{84}$

Portanto, a consciência moral não é mais do que o instinto de crueldade impedido de exteriorizar-se e que, por isso, se interioriza.

O homem que, na falta de inimigos e resistências exteriores, preso na opressora estreiteza e regularidade dos costumes, se dilacera, se perseguia, se mordia e roía, se sobressaltava, maltratava impacientemente a si mesmo, este animal a que se quer "domesticar" e que se golpeia furioso contra as barras de sua jaula, este ser a que lhe falta algo, devorado pela nostalgia do deserto, que teve que criar em si próprio um campo de aventuras, uma câmara de suplícios, uma selva insegura e perigosa - este louco, este prisioneiro desejante e desesperado foi o inventor da "má-consciência". 85

Noutra palavras, o homem é um animal feroz, quer para seu interior, quer para o seu exterior; condição essa negada pela maneira de valorar dos ressentidos, da cultura do cristianismo. ${ }^{86}$

\footnotetext{
${ }^{84}$ Fink, 1983, p.143.

85 Nietzsche, 1990, p.97.

86 Scarlett Marton (2010) nos alerta para a correta leitura do texto nietzschiano: "É pensando na aristocracia guerreira dos tempos homéricos que, na Genealogia da Moral, ele concebe o tipo de homem forte. Querendo prevalecer na relação com os demais, o forte desafia todos os seus pares. Mas não identifica a precedência com supremacia nem confunde o combate com extermínio. Entender a existência como um duelo leal é uma condição que lhe é inerente; não se pode guerrear quando se despreza e não há porque fazê-lo quando se domina. Para que ocorra a luta, é preciso que existam antagonistas; e, como ela é inevitável e sem trégua ou termo, não pode implicar na destruição dos beligerantes. Mais próxima de um jogo que da guerra total, a luta é sempre pela precedência, nunca pelo aniquilamento do adversário" (p.55-6).
} 
No terceiro tratado da Genealogia da Moral, Nietzsche traça um perfil mais demorado do sacerdote e de seu ideal ascético. Se pergunta pelo sentido do ideal ascético, de como valoram os sacerdotes a vida, a realidade. Para ele, os sacerdotes valoram a vida de uma maneira negativa, só admitem a vida se esta nega a si mesma. Essa auto-contradição é a chave do valorar sacerdotal, na medida em que inverte todos os valores:

esta vida (junto com tudo o que a ela pertence, "natureza", "mundo", a esfera inteira do devir e da caducidade) é posta por eles em relação com uma existência completamente distinta, da qual é antitética e excludente, a menos que se volte contra si mesma, que se negue a si mesma: neste caso, o caso de uma vida ascética, a vida é considerada como uma ponte para aquela outra existência". ${ }^{87}$

Isso significa que os sacerdotes chamam de "verdadeiro" um mundo inexistente, fingido por eles, inventado por eles, e em troca negam a verdade e a realidade deste mundo, o único existente. $\mathrm{O}$ ascetismo dos sacerdotes trata a vida como um caminho errado, que se deve refutar através de sua valorização da existência. Para Nietzsche, esta maneira de valorar não está inscrita na história dos homens como se fosse um caso de exceção e de raridade: é um dos fatos mais extensos e duradouros que existem na história humana. Daí que, para ele, "tem que ser uma necessidade de primeiro nível a que faz crescer e prosperar esta espécie hostil à vida, - tem que ser, sem dúvida, um interesse da vida mesma que tal tipo de autocontradição não se extinga". 88

Tal é o paradoxo em grau supremo: uma cisão que se quer cindida, que goza a si mesma nesse sofrimento de cindir-se, "que se torna inclusive sempre mais segura de si e mais triunfante à medida que diminui seu próprio pressuposto, a vitalidade fisiológica". 89 Ou seja, o ideal ascético é uma estratégia da vida fraca e doente para a conservação de sua vida. A vida fraca tem de renunciar à explosão das paixões, das emoções; ela deve sustar suas paixões, seus instintos vitais para poder sobreviver. $\mathrm{O}$ que isto expressa, no

${ }^{87}$ Nietzsche,1990, p.136

88 Idem, p.137.

89 Ibidem, p.137. 
fundo, é a condição enferma do homem, do tipo de homem que houve até agora, pelo menos do homem domesticado, civilizado, oriundo da inversão dos valores perpetrada pela moral dos escravos.

Para Nietzsche, o sacerdote asceta é "o 'falso médico' e 'salvador', que mantém no seu sofrimento a vida que sofre, a vida miserável e medíocre. Ele 'cura' a ferida de uma tal vida sofredora e envenena-a ao mesmo tempo, pelo que a ferida precisa constantemente de ser tratada" ${ }^{90} \mathrm{O}$ sacerdote

traz consigo unguentos e bálsamos, não há dúvida; mas (...) enquanto acalma a dor produzida pela ferida, envenena ao mesmo tempo esta - pois disto, sobretudo, entende este encantador e domador de animais de rapina, em cujo redor todo são se torna necessariamente manso. ${ }^{91}$

Para isso, o sacerdote modifica a direção do ressentimento: ele persuade o doente de que está enfermo por sua culpa, consolando-o com o seu ideal ascético, negador da própria vida. E ele o faz, segundo Nietzsche, instrumentalizando a culpa:

O principal ardil que o sacerdote ascético se permitiu para fazer ressoar na alma humana toda sorte de música arrebatadora e extática consistiu (...) no aproveitar-se do sentimento de culpa. (...) O "pecado" - pois assim fala a reinterpretação sacerdotal da "má-consciência" animal (da crueldade voltada para trás) - foi até agora a estratégia mais perigosa e nefasta da interpretação religiosa. ${ }^{92}$

Ou seja, a causa do sofrimento do fraco, de sua dor, ele deve buscá-la dentro de si, em uma culpa, uma parte do passado; ele deve entender seu sofrimento como um estado de pena. Ele, portanto, dá um sentido à dor da existência, estabelecendo um ideal para ela. Uma outra existência, uma verdade que rebaixa a corporalidade, triunfa sobre os sentidos, sobre a aparência visual, "uma violentação e uma crueldade contra a razão: semelhante voluptuosidade chega ao seu cume quando o auto-desprezo

\footnotetext{
90 Fink, 1983, p.144.

${ }_{91}$ Nietzsche, 1990, p.147.

92 Idem, p.163.
} 
ascético, o auto-escárnio ascético da razão, decreta o seguinte: 'existe um reino da verdade e do ser, mas justo a razão está excluída dele!". 93

Contudo, Nietzsche observa que mesmo o ideal ascético, com tudo aquilo de ruim que representa, não deixou de ser fruto de uma vontade, de uma força vital. $\mathrm{O}$ ideal ascético foi uma resposta dada à questão do sentido do homem. "Pois justamente isto é o que significa o ideal ascético: que algo faltava, que um vazio imenso rodeava o homem, - este não sabia justificar-se, explicar-se, afirmar-se a si mesmo, sofria do problema do seu sentido". ${ }^{4}$ Quando o homem se eleva à condição superior por sobre os instintos, quando ele é vontade, ele quer um ideal, um objetivo. E o objetivo que se lhe ofereceu foi o ideal ascético, predominantemente. Como algum sentido é melhor que nenhum sentido, o ideal ascético foi o mal menor até o momento. Mas qual era o objetivo da vontade ao se entregar aos ideais ascéticos? $\mathrm{Na}$ ótica nietzschiana, a vontade que subjaze ao ideal ascético é uma vontade do nada, uma tendência niilista da vida, pois o homem prefere querer o nada a não querer.

Não podemos ocultar, no final das contas, o que é que expressa propriamente todo aquele querer que recebeu sua orientação do ideal ascético: esse ódio contra o humano, mais ainda, contra o animal, mais ainda, contra o material, essa repugnância ante os sentidos, ante a razão mesma, o medo à felicidade e à beleza, esse desejo de separar-se de toda aparência, mudança, devir, morte, desejo, ânsia mesmo - tudo isso significa, atrevamo-nos a compreendê-lo, uma vontade do nada, uma aversão contra a vida, uma recusa dos pressupostos mais fundamentais da vida, mas é, e não deixa de ser uma vontade! 95

Todo esse percurso feito por Nietzsche, no sentido de desvendar a gênese dos valores morais e de seu valorar, especialmente dos valores morais relativos à cultura cristianizada, numa perspectiva muito crítica e ácida até,

93 Ibidem, p.138.

94 Idem, p.158.

95 Ibidem, p.186. 
ele o faz sob a ótica de um critério que não pode ser avaliado: a vida. A vida é o grande dado conceitual da genealogia nietzschiana da moral:

fazer qualquer apreciação passar pelo crivo da vida equivale a perguntar se ela contribui para favorecê-la ou obstruí-la; submeter ideias ou atitudes ao exame genealógico é o mesmo que inquirir se são signos de plenitude de vida ou da sua regeneração, avaliar uma avaliação moral, enfim, significa questionar se é sintoma de vida ascendente ou declinante. ${ }^{96}$

Esse é o elemento primordial da sua crítica moral, que se nos permite articulá-la à sua concepção estético-cosmológica do mundo: a vida não é mais que a manifestação do fundo primordial, do devir permanente, que está subjacente à todas as formas, à todas as aparências transitórias da existência, enfim, à finitude. $\mathrm{O}$ olhar nietzschiano sobre os valores morais busca, então, reconhecer neles ou não, essa vinculação à vida primordial, à unidade do todo. Uma moral que não reconheça essa sua raiz estético-cosmológica do devir da finitude, das coisas e do homem, é fatalmente objeto de seus escárnios. Daí decorre, fundamentalmente, suas objeções à moral do escravo, ao modo de valorar do cristianismo e ao ascetismo, pois são todas fontes de negação da vida, da auto-afirmação, da perspectiva artístico-criadora que está presente na moral aristocrata, no modo de valorar dos nobres, no reconhecimento da crueldade inerente ao homem, de sua condição de animal de rapina. A vida é o critério-mor para afirmação ou não da presença do dionisíaco, do devir primordial na compreensão do mundo que é inerente às diferentes formas de valorar e seus respectivos valores morais.

Essa ótica da vida, assumida por Nietzsche para perscrutar a valoração moral, em seu livro $A$ Gaia Ciência, ${ }^{97}$ aparece disfarçada num certo "positivismo", na medida em que

utiliza métodos que considera "científicos" para destruir a religião, a metafísica e a moral. Ele joga com o pathos da ciência e corporiza este pathos justamente na figura do

${ }^{96}$ Marton, 1993, p.62.

${ }_{97}$ Nietzsche, 1959. 
"Espírito Livre". A ciência do espírito livre é uma ciência alegre, la gaya scienza. ${ }^{98}$

O que subjaz a esse momento da obra nietzschiana é o desmascaramento da perda do homem, desse seu afastar-se de si mesmo, já o vimos na sua crítica à moral do escravo e ao ideal ascético do sacerdote, na medida em que se submeteu ao sobre-humano; e a religião, a metafísica e a moral são as formas dessa servidão. A moral do escravo, o ideal ascético, a mentira da ciência e sua vontade de verdade, a cultura apolínea enquanto negadora do dionisíaco, são reveladas por ideais forjados pelo próprio homem, como máscaras para sua "alienação" de si mesmo, negadoras da sua condição de criador de valores, como rupturas com a visão trágica da existência, de afastamento do homem de sua unidade com o devir primordial, com a torrente vital dionisíaca, o fundamento de tudo. Com a crítica proporcionada pela gaia ciência, o homem aprende que viver significa ousar, que a vida torna-se possível como experiência, experiência criadora, arte da vida; pois, como descreve Fink,

o homem já não procura no exterior os seus objetivos, mas no interior de si próprio, a vida já não tem significado antecipadamente dado, já não está presa, já não é conduzida pela vontade de Deus, já não é conduzida em andaduras pelas prescrições da moral, já não está presa, já não está condicionada por um ultra-mundo metafísico que fica além do mundo dos fenômenos, já não é entravada por nenhuma força sobre-humana - tornou-se livre. ${ }^{99}$

Esse estado de espírito de liberdade, como resultante do cultivo de uma ciência "alegre" - a gaia ciência -, Nietzsche o descreve como sendo senão

as saturnais de um espírito que resistiu pacientemente uma terrível e grande pressão (...) e que agora, de repente, se vê cheio de esperança, a esperança da cura, a "embriaguez" da cura. (...) E que este livro, todo ele, não é mais que festa

${ }^{88}$ Fink, 1983, p.56.

99 Idem, p.56. 
depois das privações e das debilidades; é o júbilo das forças que renascem; a nova fé na manhã e na manhã passada, o sentimento súbito e o pressentimento do porvir, das aventuras próximas e dos mares abertos, dos fins novamente lícitos e nos quais se pode acreditar de novo. ${ }^{100}$

Para ele, aquele que se regenerou, que saiu da enfermidade, aprendeu com os gregos, aqueles que sabiam viver, que operavam na sabedoria de que

para viver é necessário saber permanecer bravamente na superfície, na epiderme, adorar a aparência, crer na forma, nos sons, nas palavras, em todo o Olimpo da aparência! (...) Não somos nós precisamente nisto gregos, adoradores das formas, dos sons, das palavras; e, por isto, artistas? ${ }^{101}$

Aqui podemos ver, então, que a ótica da vida para Nietzsche está repousada, em última instância, na ótica da arte, na sua visão estéticocosmológica da existência.

\section{Cotejando as perspectivas macintyreana e nietzschiana}

Após esse percurso, podemos agora nos posicionarmos, mesmo que provisoriamente, acerca das teses macintyreanas sobre Nietzsche e de suas relações com este fundamental pensador da modernidade. Acreditamos que suas teses repousam numa leitura parcial de Nietzsche, o que o conduz a algumas caracterizações insustentáveis frente ao texto nietzschiano. Essa parcialidade é decorrente da necessidade de MacIntyre em afastar qualquer alternativa à retomada $\mathrm{da}$ posição aristotélica frente ao fracasso do Iluminismo em fundamentar racionalmente a moral. Para isso, subsume Nietzsche no clima emotivista da cultura pós-iluminista, forjada na modernidade, e no seu fracasso no âmbito da reflexão moral. E o faz desconsiderando que a meta-ética nietzschiana está calcada numa perspectiva estético-cosmológica da existência, na visão trágica do devir primordial subjacente a todo finito. A crítica da cultura iluminista e de toda tradição

100 Nietzsche, 1959, p.39-40.

101 Idem, p.45-6. 
filosófica ocidental feita por Nietzsche, a crítica da religião, da ciência e da metafísica como máscaras para a origem humana de todas as transcendências, são feitas a partir da ótica da vida. A conceituação de vida, do vital em Nietzsche, não se confunde com o emocional e o psicológico, é um fundamento cosmológico, um conceito do mundo: o dionisíaco como fundo primordial de todo existente.

A crítica genealógica que faz à moralidade iluminista, a busca de sua gênese, visa identificar a valoração que lhes é subjacente, através do critério da vida. Ao derrubar a transcendência ou suas fontes transcendentais, Nietzsche identifica as origens humanas, demasiado humanas, da moral, mas sem desembocar no subjetivismo, nem no relativismo morais; pois aponta uma clara opção pela moral aristocrática, na medida em que esta recolhe a fonte primordial de avaliação de todas as normas: a torrente vital dionisíaca que está por trás de todo impulso apolíneo, de toda forma que é finita. A moral dos senhores, ou aristocrata, é a moral que se reconhece no fundo primordial vital, que assume plenamente o caráter artístico como justificador de qualquer existência.

MacIntyre não considera o elemento estético-cosmológico que está presente no filosofar nietzschiano, dessa âncora da "metafísica do artista" que sustenta sua afirmação de toda e qualquer manifestação da vida primordial, na forma da aceitação trágica de todo finito como aparência, obra estética, apolínea, do devir primordial dionisíaco. Ao olhar para o mundo, Nietzsche opera uma "axiologização" do existente, e de todas as suas formas, ao avaliálos pelo prisma da ótica vital, de expressão ou não do reconhecimento do uno-primordial - que ele chama de Dionísio, a embriaguez que envolve o movimento do todo, onde as individuações se desfazem no eterno movimento de construção e destruição.

A figura do Übermensch, o super-homem nietzschiano, ${ }^{102}$ acusado por MacIntyre de ser a expressão do solipsismo moral de Nietzsche, de sua defesa do individualismo liberal, não pode ser compreendida isoladamente da perspectiva estético-cosmológica que lhe dá compreensibilidade. Ao criticar e refutar toda pretensão de fundamentação racional da moral iluminista, Nietzsche não depositou nas mãos do indivíduo, pura e

102 Sobre as diferentes e sempre discutidas traduções de Übermensch, ver Marton (2010) e as notas sobre isso em Sousa (2010), dentre outros. 
simplesmente, da vontade de poder, a possibilidade constantemente aberta de criar valores. Para ele, toda e qualquer moral só pode ser justificada, fundamentada esteticamente, ou seja, enquanto se vincula ao devir primordial dionisíaco do mundo, a visão trágica da existência. Daí porque recusar toda a moral de rebanho, a moral do escravo, que se caracteriza pela negação da vida, pela não compreensão do eterno movimento de criação e destruição de todo finito, se vinculando a um transcendente, a um além que não existe. A vontade de potência, o indivíduo, só é justificada em Nietzsche pela sua vinculação à atividade estético-criadora que está presente na torrente vital do uno-primordial, à visão dos poderes vitais da realidade do mundo trágico.

O isolamento do Übermensch, de sua não-sociabilidade com os outros homens, se justifica por ele não estar vivendo ainda no âmbito de uma cultura dionisíaca, mas numa cultura onde a moral de rebanho é ainda o predomínio, onde o niilismo negador da vida atinge o seu ápice. Nesse contexto ele não tem como deixar de parecer aos outros homens como arrogante, mentiroso e individualista. Ele não vive mais sob os desígnios de Deus, nem de uma ordem verdadeira última, metafísica; suas ações se fazem sob o signo de outros valores, humanos, demasiado humanos, em que sua condição de animal de rapina não é negada ou destruída. Assume a condição do artista criador, de integrado no mundo das aparências apolíneas, mas que não vive na "mentira" da ciência. A crítica de Nietzsche ao liberalismo é decorrente de ele não prover as condições para esse novo homem ou até mesmo destruí-las. ${ }^{103}$

O Übermensch assume plenamente a moral do nobre, do aristocrata guerreiro, da manifestação da vida, da gaia ciência. É um espírito livre, humano, autônomo, que se reconhece como forma finita do fundo primordial dionisíaco, que aceita a tragicidade inerente à existência sem se refugiar nas abstrações do mundo científico, desprovidas de vida, que recusa o ascetismo e toda a inversão de valores dele oriunda - é o homem que

103 "As instituições liberais deixam de ser liberais tão logo são alcançadas: mais tarde, não há piores e mais radicais danificadores da liberdade, do que instituições liberais. Sabe-se, até, o que essas instituições conseguem: minam a vontade de potência, começam a trabalhar nivelando montanhas e vales, e chamam isso de moral, tornam as coisas pequenas, covardes e agradáveis - elas representam o triunfo contínuo dos animais de rebanho. Liberalismo: animalização em rebanho, em outras palavras...". (Nietzsche, 2005, p.216) 
transvalorou, que assumiu na plenitude o olhar dionisíaco que Nietzsche lança sobre o mundo e suas formas culturais, que vive de uma maneira marcadamente estética, para além do bem e do mal, em que ele mesmo e o princípio de individuação se dissolvem no fundo primordial dionisíaco. Não há, assim, a afirmação de um individualismo essencial na filosofia nietzschiana, como o fazem os teóricos liberais.

Quanto ao perspectivismo nietzschiano, MacIntyre o acusa de ser um abandono da racionalidade - essa talvez seja sua tese mais contundente e mais complexa para criticar. Contudo, em Nietzsche não temos uma negação pura e simples da racionalidade, repousada numa visão simplesmente cética ou então volitiva acerca da verdade das coisas. Ao criticar a ciência, problematizando-a pela perspectiva estético-cosmológica do devir primordial, Nietzsche aponta para os seus limites, para sua "mentira" ao se pretender ser a única verdade. A visão trágica do mundo exige que se reconheça até mesmo a finitude do conhecimento. Nietzsche não pesa as verdades da ciência do ponto de vista epistemológico puro, ele desloca a questão para a ética da vida, para avaliar se as "verdades" favorecem ou não o fluir da torrente vital dionisíaca e do seu reconhecimento.

Nietzsche não afirma um puro irracionalismo, mas aponta os limites do racionalismo, o fundamento sobre o qual ele se assenta. Recusa um racionalismo que imobiliza o devir, que nega a condição trágica do mundo, do eterno retorno a ele subjacente. Ousaria dizer, mesmo apressadamente, que seu perspectivismo é mais metódico que de conteúdo, pois quando analisa criticamente a moralidade e sua gênese, não desemboca na afirmação de que toda e qualquer moral vale, uma moral constituída ao bel prazer dos indivíduos; mas afirma um ideal moral fundado na compreensão fundamental da existência humana integrada ao devir cosmológico, ao nascer e morrer, ao movimento vital e constante do eterno retorno, criação e destruição como caráter de todo existente, portanto, também de toda moral. A ideia do "espírito livre" é justamente daquele que não tem mais as amarras ontológicas, religiosas ou científico-racionais a conduzir a avaliação de sua existência; sua referência passa a ser a perspectiva estético-cosmológica da existência, o dionisíaco como uno-primordial do qual não passamos de alguns momentos transitórios, frutos de sua necessidade de expressar-se em 
formas artísticas - como não poderia deixar de ser, em um dizer sim ao mundo, tal como ele é na sua finitude. ${ }^{104}$

Dessa forma, parece que as teses macintyrianas se revelam problemáticas frente os elementos fornecidos pelo próprio Nietzsche. Elas claramente sofrem de uma leitura parcial de pontos importantes de sua filosofia, não permitindo uma crítica mais cortante destes, ao não levar em conta todos os seus elementos constitutivos. Contudo, elas apontam para um ponto importante da filosofia nietzschiana: o elemento intuitivo nela presente. O papel da intuição no filosofar nietzschiano é um dado que ele mesmo indicou na sua preferência pelo homem intuitivo em relação ao homem racional, bem como pelo mito e, especialmente, a arte, em relação à ciência. A intuição como elemento organizador do mundo, diríamos, não é um elemento muito convincente como um princípio diretor, referencial ou método organizatório da vida moral e social. Como tal, a intuição pode representar uma fuga do confronto sério entre as diferentes perspectivas, tão prezadas por Nietzsche, envolvidas no trabalho de tornar inteligível a ação humana. Intuições diferentes por indivíduos, grupos ou comunidades diferentes apelariam a que para a resolução de suas disputas no espaço político comum, uma vez que todas seriam intuições genuínas? ${ }^{105}$ Nietzsche não nos oferece propriamente uma resposta para isso.

Além disso, o referencial da vida, assumido por Nietzsche como critério último de valoração das morais, será ele próprio objeto de disputa por intuições diferenciadas. Qual vida? Vida de quem? ${ }^{106}$ MacIntyre está nos levando, com suas teses, e a despeito de seus elementos problemáticos acima apontados, a nos perguntar também pelo valor da valoração de Nietzsche.

\footnotetext{
104 "Não se trata de um tipo biológico superior ou de uma nova espécie engendrada pela seleção natural, mas de quem organiza o caos de suas paixões e integra numa totalidade cada traço do seu caráter, de quem percebe que seu próprio ser está envolvido no cosmos, de sorte que afirmá-lo é afirmar tudo o que é, foi e será". (Marton, 2010, p.59)

${ }^{105}$ Esse é um ponto que merece ser refletido com maior profundidade e mais paciência, de forma que se possa verificar se, por essa via, o filosofar de Nietzsche desemboca ou não em uma negação total da razão ou se, pelo contrário, reside nele uma vontade de afirmar uma outra forma de racionalidade, que valoriza a vida plenamente no sentido dionisíaco, que ele próprio não chegou a teorizar sistematicamente, mas que talvez tenha postulado, ao ridicularizar e levar a extremos as formas racionalistas do seu tempo

106 Nesse sentido, Nietzsche não foi, de fato, muito propositivo no aspecto de elaborar uma filosofia social e política que pudesse oferecer respostas mais claras. 0 lado descontrutivo de suas críticas prevaleceu nos seus escritos.
} 
Curiosamente, MacIntyre aplica em Nietzsche o próprio método genealógico nietzschiano, ao inseri-lo na história da moralidade do Ocidente em After Virtue; ao buscar as raízes da atual crise moral, cava a superfície da cultura moderna em busca das camadas que ficaram escondidas e que estão na base de nossos problemas, e das quais Nietzsche faz parte.

Entretanto, a nosso ver, MacIntyre parece mais nietzschiano do que avalia ser. Ao assumir o diagnóstico nietzschiano da moralidade moderna, acabou assumindo deste ferramentas de compreensibilidade da vida moral. MacIntyre compartilha com Nietzsche a visão do conflito como expressão da dinâmica do mundo moral, essa física do movimento que se instalou visceralmente após a emergência do mundo moderno, mas que já estava presente na visão trágica contida no teatro grego de Sófocles: a possibilidade de que na vida moral nem sempre temos escolhas simples, mas pode haver situações em que haja a impossibilidade de uma única escolha certa, pelo fato de as alternativas serem igualmente válidas. Dai porque MacIntyre buscar formular uma racionalidade do confronto das tradições, mas assumida sem qualquer princípio universal a priori a regulá-lo, como saída para as querelas morais contemporâneas. Compartilha com Nietzsche o gosto pela historicidade da vida moral, daí ter assumido metodicamente a genealogia nietzschiana para realizar sua genealogia da moralidade moderna em After Virtue, mas ao mesmo tempo voltando essas ferramentas contra o próprio Nietzsche.

Enfim, parece haver por parte de MacIntyre uma troca dialética com Nietzsche em termos filosóficos, enriquecedora de sua própria perspectiva teórica, mas não uma mera recusa de um autor avaliado como tendo caído no erro. ${ }^{107}$ Se torna Nietzsche alvo de suas críticas, ao mesmo tempo reconhece nele uma contribuição filosófica fundamental no debate moral, assumindo ferramentas conceituais destes para sua própria reflexão sobre a crise moral contemporânea e suas raízes culturais.

107 Uma familiaridade que gera, por exemplo, a hipótese de haver uma certa convergência entre MacIntyre e Nietzsche, não uma exclusão mútua. Sobre isso, ver o trabalho de Sousa (2010). 


\section{Referências}

CARVAlHO, H. B. A. de. Tradição e racionalidade na filosofia de Alasdair MacIntyre. São Paulo: Editora Unimarco, 1999.

COELHO, M. Nietzsche fundou terrorismo do pensamento. Jornal Folha de São Paulo. 20 de maio de 1994. p.05, Seção Ilustrada.

FINK, E. A filosofia de Nietzsche. Lisboa: Editorial Presença, 1983.

FERRY, L. et alii. Porque não somos nietzscheanos. São Paulo: Ensaio, 1994.

MARTON, S. Nietzsche, filósofo da suspeita. Rio de Janeiro: Casa da Palavra; São Paulo: Casa do Saber, 2010.

Nietzsche, das forças cósmicas aos valores humanos. $3^{\circ}$ ed. Belo Horizonte: Editora UFMG, 2010b.

__-_. Nietzsche - A transvaloração dos valores. São Paulo: Moderna, 1993. (Coleção Logos)

Ensaístas promovem uma demolição de Nietzsche. Jornal Folha de São Paulo. 24 de abril de 1994. p.06/10.

MacINTYRE, Alasdair. After Virtue. 2º ed. London: Duckworth, 1985.

Three rival versions of moral enquiry: Encyclopaedia, Genealogy, and Tradition.

Notre Dame: University of Notre Dame Press, 1990.

. Justiça de Quem? Qual Racionalidade? São Paulo: Loyola, 1991.

NIETZSCHE, F. La genealogia de la moral. Madrid: Alianza Editorial, 1990.

__-_. O nascimento da tragédia. São Paulo: Cia. das Letras, 1992.

___. El gay saber. Obras completas, Tomo VI. Buenos Aires: Aguilar, 1959.

. Verdade e mentira no sentido extra-moral. Os Pensadores. $3^{\circ}$ ed. São Paulo: Abril Cultural, 1983. pp.43-52.

. The Anti-Christ, Ecce Homo, Twilight of the Idols, and Other Writings. New York: Cambridge University Press, 2005.

. On truth and lies in a nonmoral sense. In: Ansell-Pearson, K. \& Large, D. (eds). The Nietzsche Reader. Oxford: Blackwell Publishing, 2006, p.114-123.

SOUSA, J. E. de. As alternativas à condição moral moderna segundo Nietzsche e MacIntyre: um confronto entre Genealogia da Moral e Depois da Virtude. Teresina: Universidade Federal do Piaú, Mestrado em Ética e Epistemologia, 2010. (Dissertação). Acessado em 28 de agosto de 2010 no endereço: $<$ http://www.ufpi.br/subsiteFiles/eticaepistemologia/arquivos/files/Dissertacao_Elielt on_2010(2).pdf> 
TANNER, M. Nietzsche - A very short introduction. Oxford: Oxford University Press, 2000.

VOLPI, F. O niilismo. São Paulo: Loyola, 1999.

Email: buenos36@hotmail.com

Recebido em: Setembro/2010 Aprovado em: Novembro/2010 